\title{
Tahsin Method of Al-Quran and Parenting for Children Hyperactive in Kindergarten School Orange, Ciputat Timur, Tangerang Selatan, Indonesia
}

\author{
Ati Kusmawati \\ Airlangga University, Surabaya, Indonesia \\ Muhammadiyah Jakarta of University, Jakarta, Indonesia \\ Corresponding e-mail: ati2051976@gmail.com
}

\begin{abstract}
Hyperactive children are part of an interesting issue for education. This study aims to determine the method tahsin Qur'an can reduce excessive activity in hyperactive children and parenting involvement in hyperactive children. The subjects of this study using two boys ages 5 years and 7 years indicated hyperactivity in kindergarten Orange School, East Ciputat, Indonesia This study using observation and interview. Starting with the observation and then use the interview guide was developed by researchers gradually. Interviews were conducted intensively on students who indicated hyperactive, teachers and parents. For the method tahsin through the intervention of the Qur'an (juz 30) to the children before they learn in the classroom. The results can be inferred through method tahsin Qur'an conducted intensively (3 months) to students who indicated there was a drop hyperactive hyperactive behavior significantly. As Students are also able to follow before the class to say hello, shake hands with the teacher, to pray before the study even though the movements interfere with her sometimes still appear, students will follow the activities in the classroom with her friends despite initially difficult to set up and requires a long time to can adapt and work together in the classroom.
\end{abstract}

Keywords: $\quad$ tahsin Qur'an, parenting, hyperactive

\section{INTRODUCTION}

Children with special needs is currently a significant concern by the government and society. It is also Undang-Undang Nomor 20 tahun 2003 on National Education System pasal 32 has arranged special education and special education services. The implementation is described through Permendiknas nomor 70 tahun 2009, by providing opportunities and opportunities for children with special needs to obtain regular school education from elementary school, junior high and senior high school/Vocational. However, Schools are generally located in needs spread almost throughout the districts and villages. As a result, the majority of children with special needs, especially the weak economic capacity of their parents, forced into special schools were not in school because of the location of the school away from their residence.

\section{LITERATURE REVIEW}

Hyperactivity is caused by a disturbance in the centre of attention and neurological disorders in the brain motor. Hyperactive children in medical terms as Discorded Attention Deficit Hyperactivity (ADHD). This hyperactive child has specific characteristics that can be seen and distinguished with normal children in general. The inability of the child in focus, attention and concentration and tend engrossed in his own world. ADHD is a disorder neurobiologist whose characteristics have been seen in children from childhood.

Children with ADHD are starting to show a lot of problems when SD as required to heed the lessons quietly, studying various academic skills, and get along with peers according to the rules (Gianjar, 2009). In general, children with ADHD have a high motor activity compared to his age, it is difficult to follow the instructions sequentially and easily 
forgotten. Several therapeutic techniques have been made to reduce the symptoms of ADHD include cognitive behavioral therapy that but this will change the mindset of people with ADHD in the face of certain conditions; psychological therapy with the goal of finding ways that can be used to treat symptoms of ADHD sufferers are asked to tell all in feel to the psychologist; social relations training with the aim that people with ADHD can feel like a social being done training in how to interact with others; and behavioral therapy with the goal of motivating people with those closest to the patient can give praise and be trained so that patients can behave like ordinary people both in everyday life and in time to meet a difficult situation. As in the study Roshinah, et al (2014) through murottal therapy can help reduce symptoms of hyperactivity and impulsivity levels in children with ADHD. This therapy helps children hyperactive and impulsive for learning and training articulation of the ADHD child.

The results of this study show the influence murottal therapy on decreasing the symptoms of the research subjects. At first the symptoms were still in the range of six symptoms but at this stage of the second observation, the symptoms had decreased to three symptoms. Although the frequency appears unstable. Murottal therapy has been associated with hyperactive behavior in children with ADHD impulsive. Murottal therapy is calm children with ADHD. When played murottal readings under normal circumstances, slowly fade research subject for calm.

When the readings are trained to recite the Qur'an, the study subjects slightly improve articulation and pronunciation. Murottal therapy is recommended to relieve the behavior of children with ADHD. In addition, it takes care of the parents intensively against children in order to have a concentration so as to carry out activities in accordance with its development. Family environment is an environment closest to the child, so the family can be a cause aggressive behavior. Aggressive behaviour was raised due to the tendency of certain parenting from their parents. Pattern foster parent is an interaction between parents and children during the conduct of care, and every parenting contributes to aggressive behavior.

Contributions given can be negative or positive. In this regard, parents should be increasingly aware of its position and implement parenting is best for her child. Similarly, for children with ADHD who do have differences on other children, requires parents to care for children with greater attention. Research Aisyah (2010) care to children situationally. But have suggested that parents more dominant in democratic parenting style, because the type of parenting the negative contribution to the emergence of aggressiveness. In contrast to this research, how the Qur'an tahsin method capable of lowering the emotions of children with hyperactivity and how the parenting of children hyperactive. Tahsin associated with, research Mafaza (2008) showed that: 1) The model of learning to read the Qur'an held in SD Muhammadiyah Sapen is Iqra Intensive Model. Told intensified since the beginning, the learning is only for grade one, in a period of approximately 4 months, the intensity of the meeting was high that every day for four months, with the intensity of the meeting were high that every day for approximately 1 hour. Told intensively for this program emphasizes on improving the ability of every child to read (not write or memorizing) the Qur'an. As for how the delivery of the material in general use private method, so within that time, the child is able to read the Qur'an properly; 2) There are several factors in the implementation of learning to read the Qur'an, either in the form factor of implementation of support or that inhibit learning. As for the factors inhibiting are: first, the number of students who pretty much (254 students), second is the learning time is fairly short, the third of their holiday or pause long enough time learning still takes place, the fourth is the transition of students from kindergarten to SD, then the differences in student background, ranging from differences in social status, economic level, religious understanding, origin and other regions, and the latter their differences in the level of students' skills in reading the Qur'an.

As for some of the supporting factors, among others: a) program is an annual program that the school has experienced; b) recruitment of teachers Iqra from outside the school who doing selectively, c) the number of teachers Iqra adequate, d) the support of teachers, principals and employees, e) the availability of facility facilities, especially books Iqra for each student and study room adequate, then held for regular meetings between the parents with the school to consult on student progress in learning to read the Qur'an and the last is the time provided in the morning. 3) The success rate of the program of learning to read the Qur'an comes from the firstgrade students of the school. So, for the learning program Qur'an grade students of the 2007/2008 academic year, is known to have graduated 254 students. The result is 15 students vol 6 , student's volume 5, 1 vol 3 students and 1 student volume 4 .

Erfiana (2015) in research related to tahsin recitations, the results of the research are: 1) the background of the implementation of the program and Tahfidz tahsin the recitations of the Qur'an for female students of Pondok Pesantren Darut Taqwa is to improve the quality of reading al-Qur'an students 
who still low and regulations of the Islamic School of Integrated Network (JSIT) advocating national institutions under its part to promote the education of the Qur'an; 2). Implementation of the program and Tahfidz tahsin the recitations of the Qur'an at Pondok Pesantren Darut Taqwa Ponorogo includes the preparation phase, namely the holding of management for cleric cleric and held division of the group for the students; the implementation phase, using sorogan method; evaluation phase either end of each semester or even the odd semester exams held tahsin recitations and Tahfiz al-Qur'an.

Tahsin method in Kholifa (2010) with the result that the overall activity of classroom action research are used in research by students of class V SD Islam Cahaya Ummat Bergas of Semarang in the academic year 2009/2010 in accordance with the purpose of research is to improve the recitations of al-Qur 'an through Tahsin method. By using a number of class action 3 cycles: a) learning method can improve the Tahsin al-Qur'an recitations students according makhroj, the nature of the letter and recitation. It can be seen from the observations in the ability of the Qur'an recitations from pre-cycle I $=53 \%$; b) The learning process using the method can maintain recitations Tahsin al-Qur'an student of a fatal error, so as to maintain the reading remains true. It is shown the acquisition value of the motivation of the first cycle $=67$ and to the second cycle $=87 \%$; c) Learning recitations of the Qur'an by using tahsin method can improve the performance recitations of al-Qur'an students, it is indicated on improving achievement second cycle $=87 \%$ for the third cycle $=100 \%$. Thus, mastery learning recitations of alQur'an succeeded 100\%.

Deferent from Ramadan et al (2011) who studied the tahsin learning application based on Android. With the results of his research is the application could provide an example of reading moves and reading verses gharib using voice media, this application can also provide an example of reading the letter hijaiyah using video media, as well as this application can also provide material about the laws of tajwid using text. The same study relating to tahsin and applications on android by Purwati (2015), this study aims to develop a learning application tahsin Qur'an on windows phone 7 platforms, knowing the results of analysis of the quality aspects correcteness, knowing the results of analysis of the quality aspects of functionality and knowing the results of analysis of usability aspect, for the platform Windows Phone 7. research results obtained: 1) product application tahsin learning the Qur'an can run on smartphones based on Windows Phone 7 ; 2) the results of analysis of both correctness produces 3615 lines of program code with an error density of 0 to meet the standards, analysis of both functionality and contributing produces primary function is running as expected output that is included in the category of "very decent". Based on the standard used on each aspect of your test, all results show that learning application tahsin Qur'an on the Windows Phone 7 platform fulfils the quality software for correctness aspects of functionality, and usability.

Several studies above, it can be concluded that the method tahsin has done an assortment of Iqra intensive, recitations, sorogan, to use Android. But more often used in an educational environment is the traditional method (Iqra, recitations, and sorogan). In contrast to what researchers will do that using intensive method tahsin recitations. This means that researchers will continuously practice of reading the Qur'an in order to be true to the students with hyperactivity. Problems-problems above be of interest for the author to examine the method tahsin Qur'an and upbringing in hyperactive children in kindergarten Orange School, Ciputat Timur, Tangerang Selatan.

\section{TAHSIN METHOD}

One effort to studying the Qur'an is studied tahsin. Tahsin is a language derived from the word assanaYuhassinu-Tahsin, which means smarten or make your own good. Reading the Qur'an to say good when read in accordance with the rules of the science of recitation. While the recitation is a science that provides the sense of the letter, both the rights of any letters or new laws that arise after the right of the letter are met, which consists of properties and forth like a mad law tarqiq, tafkhim. According to Rauf (2003) tahsin method is one way to recitations of the Qur'an, which focuses on makhroj (where the discharge letter) and the science of recitation. This method in the study the Qur'an through a teacher directly or confronted. As in the study Kholifah (2010), it can be concluded that learning with tahsin method in class V SD Islam Cahaya Ummat, Bergas of Semarang can improve student recitations of the Qur' an according makhroj, the nature of the letter and recitation.

Based on observations in the ability recitations of the Qur'an from the pre-cycle to cycle I is 53\%; learning process by using method tahsin can keep recitations of the Qur'an student from a fatal error, then able to keep reading remains true. Acquisition and shown motivational value of the first cycle is $67 \%$ to $87 \%$ amount of the second cycle and the third cycle increased to $100 \%$. Thus, mastery 
learning recitations of the Qur'an succeeded $100 \%$. Other research by Winarti (2014) the implementation of learning the Qur'an by the method through observation tilawati 3 times in MTs Assakinah west of Bandung, the class VII is good with the reason most students responded agreed that if this method is used and is very interesting because it uses a classical approach to teaching and individual approach with techniques refer to read, easy to understand the material presented for using the song rost 3 tone (flat, up and down), the media and the means used to help understand the material.

The result students are able to read the Qur'an for the better and correctly, is able to control the reading independently and during the first year of implementation of learning students are able to ride 2-3 times the volume. This method can be used in guiding the students in the school to read the Qur'an. Erita (2014) in his study of different subjects, namely the elderly. Unknown 7 (63.64\%) of mild depression, 3 people $(27.27 \%)$ moderate depression, and $1(9.09 \%)$ severe depression before being given tahsin Qur'an, while after being given tahsin AlQur'an unknown 11 (100\%) no depression (normal). The test results obtained Paired t-test $\mathrm{p}$ value of $0.000<0.05$, meaning there tahsin influence of the Qur'an to the decrease in the level of depression in elderly PSTW Abiyoso unit Pakem, Yogyakarta. The conclusion is tahsin Qur'an guiding affect the level of depression in the elderly in PSTW unit Abiyoso Pakem, Yogyakarta. From some research on the above, it can be concluded that the method tahsin able to reduce the level of depression in a person and capable of self-control students in learning. The difference that researchers do is tahsin and parenting method in hyperactive children in kindergarten. It became an interesting study because a different subject that is a hyperactive child.

\section{PARENTING}

Parenting for parents identified through their attention and warmth, the parents in parenting and an interpersonal relationship with the child realize their attention, appreciation and affection, freedom initiative, the willingness of parents to provide opportunities for children to express and develop the idea of ideas, thoughts keeping in mind the rights of others, values and norms; directional control, ie the pattern of supervision and parental control by providing guidance, direction and supervision of the attitudes and behavior of children; assigning responsibility, namely the willingness of parents assign roles and responsibilities to the child for everything that is done. Parenting here, especially on children with special needs (hyperactivity) is extra and require very much time. Ellis and Joel Nigg (2009) The purpose of this study was to evaluate the relationship between ADHD children and parents who themselves do their own parenting. Parenting is done through a dimensional approach to ADHD, ADHD status of parents and children with disturb comorbid behavior. Previous literature has not found a significant relationship between parenting practices and ADHD, especially with ODD or CD account. Too few studies have examined the effects of this, particularly in both the mother and father, a lack of clarity about the specificity of the effect as noted in reviews. In this study, both inter-group (diagnose ADHD) and regression analysis (ADHD symptom domain) produced evidence of unique parenting practices associated with ADHD. This effect is most obvious, however, to the father, discipline is not consistent, especially fathers, to a lesser extent, low involvement. It is important to note that the discipline is inconsistent mom and dad and the low involvement of fathers is associated with fulfilling DSM-IV criteria for ADHD, independently of ODD or CD diagnosis. Maternal effects are limited to ADHD-C, whereas the effects of father performed in both ADHD subtypes. All of this appears at least partly in the analysis dimension but with certain associated domains of parenting father with the child's symptoms are inattentiondisorganization. Although not many ADHD Children's literature related to parenting. From previous research into the father's lack of attention to important things to note. Because in addition to the mother who was instrumental in the care of hyperactive children, the father is also very important role to make children hyperactive decreased emotions so he could carry out his duties as a student at the school. Parenting is clear that the word covers all aspects that most have little or no potential to stimulate aggressive in children's care. This research result in a finding that the parent parenting practice is eclectic, to child care means doing situationally. However, parents are advised more dominant in democratic parenting style for the type of parenting not contribute negatively to the rise of aggressiveness. It can be concluded that parenting is built by each of parents in educating their children is very diverse, but more raised in the study is parenting democratic. What distinguishes 
with other studies that did not focus on one care for hyperactive children comfortable with one parenting it is done parenting when it uses parenting is convenient for them because of the condition of hyperactive children emotionally unstable. relating to the maintenance, care, support and assistance so that people stand and live a healthy life (Donelson, 1990). Relation to the research that parents should be more aware of the position and apply the parenting.

\section{HYPERACTIVITY}

Hyperactive behavior can be experienced by children who have attention deficit disorder. It is characterized by traits often moving, answered quickly before questions have been completed, it is difficult to wait their turn, interrupted the game in progress, it is difficult to play quietly, difficulty concentrating and difficult to regulate the activity. Children who behave hyperactive be at high risk such as failure at school, experiencing serious social problems, including trouble getting along well as conflict with family members, often scolded and punished by a caregiver, hated by friends at school, even given the label as a bad boy. All of these factors can influence the onset of chaos attitudes and behavior of children. Hyperactive children showed a persistent pattern of behavior in a child. This behavior is characterized by an attitude does not want to be silent, unable to concentrate and act on their own or impulsive.

Hyperactive children are always moving and never feel the fun games or toys that are liked by other children their age, because they like to switch attention from one focus to another. They seemed to endlessly searching for something interesting and exciting but it never came. If ADHD is defined generally describes the condition of children who show symptoms-symptoms (traits or symptoms) lack of concentration, hyperactivity and impulsivity that can cause an imbalance activities most of their lives. In fact, ADHD is not always accompanied by hyperactivity disorder. Therefore, the term ADHD in Indonesia. Children who have ADHD or GPP/H often overlap with other conditions, such as dyslexia, dyspraxia, and fight against interference. Hyperactivity is general movement excessive by his age. Usually, since their babies move a lot and it is difficult to be soothed. When compared with active individuals but productive, hyperactive behavior seemed not intended. They are not able to control and coordinate the activities of motor, so it cannot be distinguished movement is important and not important. His movements were performed continuously without being tired, so that difficulty centre for attention. As in Vygotsky's theory suggests that the development of children depends on the interaction with people and tools that provide culture to help shape their own view of the world. There are three ways a cultural tool can be transmitted from one person to another. The first is learning to imitate, in which one person tries to imitate or copy others. The second way is to learn instructed that involves remembering the instructions of teachers and then use these guidelines to regulate itself. The last way that the tool culture is passed to other people through collaborative learning, involving a group of colleagues who are trying to understand each other and work together to learn a particular skill (Kirch, 2014).

\section{CHARACTERISTICS AND CAUSES OF HYPERACTIVITY}

Growth and development of the individual as well as the necessity to study the knowledge, skills, and ability to socialize in the community is a complex blend. If someone wants to develop his personality he must learn to control emotional impulses, so as to harmonize and stabilize feelings and actions. Besides able to focus and to develop something that will be done properly and correctly. Wiguna (2007) suggests the characteristics of children who tend to hyperactive (1) cannot sit still in the classroom; (2) hand moves uneasily; (3) sometimes run around and climb on the table and climb the teacher; (4) difficulties in playing or in fun activities together that require a lull in play or in fun activities together that require sobriety; (5) impulsivity, difficulty in waiting; (6) answers before questions have been completed / often interrupting others. Hyperactive children showed all or nearly all of the features above. Martin (1994) explained that there are several factors that cause hyperactive behavior: (1) factor neurological birth process by means of extraction forceps, babies born weighing under 2500 grams, mothers give birth too young, maternal smoking and drinking; (2) genetic factors, about $25-35 \%$ of parents and brothers are still small decreases hyperactivity in children; (3) dietary factors, dyes, preservatives and vitamin deficiencies; (4) The psychosocial and environmental factors. Sometimes hyperactivity disorder is the impact of parenting is 
less effective, for example, factor-indulgence and lack of instil discipline.

In addition, some factors that cause children to be hyperactive than parenting is less effective among others: (1) indulgence, children who are too spoiled often choose their own way in order to fulfil their needs, he will deceive his parents to get what he wants, lacking discipline given by parents to children. How like that make a child do her at will. Children who pampered usually when at school he would choose a walk and stand on the listen/obey the teacher's instructions, (2) lack of discipline and supervision, children who lack discipline or oversight will do as he pleases, because his behavior is less restricted, what do leave without any attention from parents. If the child is left without attention, the children will do as he pleases while elsewhere either at school. Discipline becomes an important part in educating children, especially children hyperactive. To be disciplined as shown in the study D.H. Schunk and B.J. Zimmerman (1998) self-regulated learning show to learn the most happening of thoughts, feelings, strategies and the resulting behavior learner himself addressed to the achievement of the goal. Self-regulated learners not only need to have cognition (knowledge to build upon), and metacognition (knowledge and monitoring learning strategy), but they have to be motivated to use strategies metacognition to build an understanding that personal capabilities that enable learners become learners are independent and self-defence (resiliency) is highly correlated with achievement. Self-regulated according to Bandura (1977) as the ability to control their own behavior and also hardworking. Bandura (1997) that self-regulated is how one is able to organize itself, influence its behavior to set up the environment, create cognitive support, as well as the consequences for their own behavior. Pintrich (1990) defines self-regulated as a process that is active, constructive, where learners set their learning goals and then monitor, manage, and control their cognition, motivation, and behavior of those who are guided by their objectives and in terms of contextual to the environment, Selfregulated learning refers to the process that uses the student to focus the mind, feelings, and actions systematically to goal achievement (Zimmerman, 1990). Research on self-regulation during the learning begins as the development of psychological investigations into the development of self-control by adults and children (Zimmerman, 2001). Much of the research on self-regulation earlier done in the clinical context, in which researchers taught participants to change behaviour dysfunction, such as aggression, addiction, sexual perversion, conflict in personal and behavioral problems at home and at school (Mace \& West in Schunk, 2012), selfregulated learning can arise in various forms. Most known, self-regulated learning that involves behavior, when a person regulates their behavior to make themselves focused on achieving the goal. But self-regulated learning also involves cognitive variables and variables that influence. To that, when engaged in learning activities, will be beneficial for learners to maintain self-efficacy for learning, believing that the positive results will arise, and maintain a positive emotional state (for example, enjoy what they are doing). Thus, self-regulated learning requires setting, management, control over all the resources, capabilities and efforts by the individual concerned to achieve the goals or achievements to be increased. Unlike the tunalaras, clearly disturbed emotionally incapable of governing themselves, are not able to manage and control themselves so self-regulatednya very low.

Based on the foregoing, it can be concluded that students with hyperactive need guidance to achieve discipline with good self-rule so that they can carry out their duties as student learning and getting better. Hyperactive children are also in need of and not in spite of his problems, namely: (1) the need for selfcontrol among others: (a) routine, structure and consistency; (b) focus on the positive things; (c) explanations simple and brief; (d) avoid arguments and escalation; (e) ignore things that are not important. (2) the learning needs: a hyperactive child in need of self-development is through learning. Because of the barriers, they experienced the fulfilment of the need for learning in hyperactive children is not as smooth as the children in general. Without the help of specially designed to be difficult for the child to be able to learn optimally. He will find it hard to optimize their potential. Though in general the potential for relatively good intelligence, even as children in general. The hyperactive child who is the subject of this study was a hyperactive child who cannot sit still and less focus on learning so distracted. Subjects were taken from a school kindergarten Orange School in Tangerang Selatan. And this also be of interest to examine the author of hyperactive children in the school. 


\section{METHOD AND RESEARCH SUBJECTS}

The subjects of this study using two boys (ages 5 years and 7 years) and four parents of children who indicated a very aggressive hyperactive criterion, cannot be quiet, hard to get along with their peers, and it was hard to concentrate. This study uses qualitative research with in-depth observation and interview techniques. Starting with the observation and then use the interview guide was developed by researchers gradually. Interviews were conducted intensively on students with hyperactivity. Tahsin to use intervention method at the Qur'an that have been determined to be Juz 30th in short letters (An-Nas to Al-Fill) and easy for children before they learn in the classroom.

\section{RESEARCH RESULT}

This research resulted in some of the notes is through a tahsin method of Al-Qur'an done intensively for 3 months at a time (one full week week except Saturday) at school before starting learning in the (hyperactivity) in kindergarten Orange School, Ciputat Timur, Tangerang Selatan, Indonesia slowly changed in such activities would not be set, less concentration, cool with his own world. After getting the intervention tahsin intensive Qur'an (3 months) to students who indicated there was a drop hyperactive hyperactive behavior significantly. As Students are also able to follow before the class to say hello, shake hands with the teacher, to pray before the study even though the movements interfere with her sometimes still appear, students will follow the activities in the classroom with her friends despite initially difficult to set up and requires a long time to can adapt and work together in the classroom. Similarly, the care applied by the parents of the subject. They realize the importance of helping the schools at home to recover his hyperactive as do tahsin method of AlQur'an intensively at home alternately father and mother. If time does not allow parents (absent) then assisted by a tutor for a while. It becomes important for parents and school success. Full attention and guidance from all sides so that students were able to complete the task hyperactivity in the classroom as students.

\section{CONCLUSION}

The authors concluded that students with hyperactivity remains a person who always get help, support schools, teachers, and parents to continue to get the change in him being personally develop in accordance with its development. In older people should continue to provide a strong motivation both morally and spiritually for his son who provide care in accordance with the situation of children and provide opportunities for hyperactive children to get an education and good care so that every child can get up and have a chance to achieve the ideals goals. Social support is required from all parties, including (1) education at home parents who focus on the education of their children in a good way, instilling discipline (self-regulation) in children, instill moral values and religion; (2) school: teachers are expected to work equally well for parents to follow the progress of their students; (3) The environment should provide positive support for the environment means providing facilities in accordance with their development. Results interventions to tahsin method of Al- Qur'an can make students want to learn to calm, focus, emotions controlled, attend classes and be nice. This all still need the help of the school, especially teachers and parents continuously role for the good of students with hyperactivity.

\section{BIBLIOGRAPHY}

Aisyah, St. (2010). Pengaruh pola asuh orangtua terhadap tingkat agresivitas anak. Jurnal Medtek, April. Volume 2., Nomor 1.

Azis, Abdul., Abdur Rauf. (2003). Pedoman Dauroh Al-Qur'an. Jakarta. Markaz Al-Qur'an.

Bandura, A. (1977). Social Learning Theory (Englewood Cliffs. NJ: Prentice Hall Publishers)

Delson, Elaine (1990). Women : A Psychological Persfective. John

Wiley \& Sons.Inc. Ellis, Brandi and Joel Nigg, Parenting Practices and AttentionDeficit/Hyperactivity Disorder: Partial Specificity of Effects. J

Am Acad Child Adolesc Psychiatry, 2009 Feb; 48 (2): 146-154, DOI : 10.1097/CHI.0b013e31819176d0

Erfina, Ulum. (2015). Implementasi program tahsin pada tilawah dan tahfidz AL-Qur'an di Pondok Pesantren Darut Taqwa Putri Ponorogo. STAIN Ponorogo : Skripsi. Tidak diterbitkan. 
Erita. (2014). Pengaruh Membaca Al-Qur'an dengan Metode Tahsin Terhadap Depresi pada Lansia DI Panti Sosial Tresna Werdha Unit Abiyoso Pakem Yogyakarta. Naskah Publikasi Ilmiah. PSIKFIKES, UMY.

Kirch, Susan A. (2014). Integrating Vygotsky's theory of relational ontology into early childhood. Science education. DO1 10.1007/s11422-013-9532-5

Kholifah, Ani. (2010). Upaya meningkatkan kemampuan tilawah Al- Qur'an melalui metode tahsin pada siswa kelas V SD Islam erpadu Cahaya Ummat Bergas Kabupaten Semarang. Skripsi, (tidak diterbitkan) STAIN Salatiga.

Mafaza, Nazid. (2008). Model pembelajaran membaca al-Qur'an siswa kelas satu Sekolah Dasar (studi kasus di SD Muhammadiyah Sapen Yogyakarta). Skripsi : tidak diterbitkan .UIN Sunan Kalijaga, Yogjakarta.

Martin, Grant. (2008). Terapi untuk anak ADHD, anak hiperaktif, sulit konsentrasi, tidak aktif, kurang perhatian. Jakarta : Bhuana Ilmu Populer.

Ramadhan, Fauzan. Et al. (2011). Aplikasi pembelajaran ilmu tahsin (MAQDIS) berbasis android.STT Telkom : Bandung.

Rosinah, F., Laila, N, \& Saiful A. (2014). Pengaruh terapi murottal terhadap tingkat hiperaktifimpulsif pada anak attention deficit hyperactive disorder (ADHD). Universitas Negeri Yogyakarta : PELITA, (IX : 2) :141-145.

Pintrich, P.R. dan De Groot. (1990). Motivation and Self-Regulated Learning Component of Classroom Acedemic Performance. Journal of Education psychology, (82,1,hlm. 33-40).

Purwati, Dwi Ika. (2015). Pengembangan dan analisis aplikasi pembelajaran tahsin al-Qur'an pada Platform Windows Phone 7. Univ. Negeri Yogyakarta : Skripsi. Tidak diterbitkan.

Widowati, S. Nurcahyani Desy. (2013). Hubungan antara pola asuh orangtua, motivasi belajar, kedewasaan dan kedisplinan siswa dengan prestasi belajar sosiologi siswa kelas XI SMA Negeri I Sidoarjo Wonogiri. Skripsi (tidak diterbitkan). FKIP, Universitas Negeri Surakarta.

Winiarti, Wina. (2014). Studi deskriptif tentang pengelolaan pembelajaran Al-QUr'an dengan metode tilawah pada siswa kelals VII di MTs Assakinah Bandung Barat. Prosiding Penelitian
Sivitas Akademika, Unisma (Sosial dan Humaniora).

Zimmerman,(1990). Self-Regulated Learning and Academic Achievement: An Overview. Education Psychologist, 25(1), 3- 17. Lawrence Erlbaum Associates,Inc ., D.H.Schunk.(1998). Self regulated learning Learning : From Teaching to SelfReflective Practice. New York : Guilford Press , (2001). Theories of Self-Regulated

Learning and Academic Achievement : An Overview and Analysis. In B.J. Zimmerman \& D.H. Schunk (Eds.), Self-Regulated Learning and Academic Achievement: Theoretical Persfectives (2nd ed., pp.1- 38). Mahwah, NJ : Lawrence Erlbaum Associates, Inc. 